\title{
Identifikasi Alkaloid Daun Kelor (Moringa oleifera L)
}

\author{
Susilo Yulianto ${ }^{1 *}$ \\ Politeknik Kesehatan Surakarta Jurusan Anafarma \\ * Email : susilo_yulianto14@yahoo.co.id
}

\begin{abstract}
Background: Indonesia has a lot of storing a variety of healthy plants and inhabited by various tribes with different traditional sanitary knowledge. Moringa leaf is a plant that is often used by the community to improve health. This type of research is an observational study that is to identify Moringa leaf alkaloid compounds. The purpose of this study was to identify the content of alkaloid compounds in moringa leaves which were arranged using tables and narratives. Methods: Descriptive observational research by extracting 260 grams of Moringa leaves, and identification in the laboratory. Results: The results of the identification of moringa leaf alkaloids using Wagner reagents contained brown sediment. Conclusion: The conclusion is positive Moringa leaves contain alkaloid compounds.
\end{abstract}

Keywords: Identification, Alkaloids, Moringa Leaves.

\section{PENDAHULUAN}

Ramuan herbal telah menjadi bagian budaya dan kekayaan alam Indonesia. Ramuan herbal merupakan bagian dari obat tradisional Indonesia yang berupa bahan tumbuhan, bahan hewan, bahan mineral, sediaan sarian (galenik) atau campuran dari bahan tersebut yang secara turun temurun telah digunakan untuk pengobatan dan dapat diterapkan sesuai dengan norma yang berlaku di masyarakat (Katno, 2008).

Pertumbuhan bakteri flora normal berlebihan maka akan mengakibatkan infeksi dan alergi pada kulit. Penyakit yang disebabkan oleh infeksi merupakan salah satu permasalahan dalam bidang kesehatan yang dari waktu ke waktu dan terus berkembang. Infeksi merupakan penyakit yang disebabkan oleh berbagai mikroorganisme seperti virus, bakteri dan jamur (Gibson,1996).

Salah satu pengendaliannya menggunakan cairan antiseptik yang diharapkan dapat mengurangi pertumbuhan bakteri, virus dan jamur.
Cairan antiseptic dapat berupa sabun cusi cuci tangan.

Tanaman yang dapat menghambat pertumbuhan bakteri yaitu kelor, daun kelor mengandung senyawa yang berpotensi sebagai antibakteri dikemukakan nurhanafi (Budi, 2014). Daun kelor mengandung tanin katekol, tanin galia, flavonoid, saponin, antrakinon, dan alkaloid. Senyawa tersebut mempunyai kemampuan sebagai obat, manfaatnya yaitu sebagai perawatan kulit, antiinflamasi, antihipertensi, anti jamur dan antibakteri (Mardiana, 2012). Pada konsentrasi ekstrak daun kelor $75 \%$ mempunyai daya hambat paling besar terhadap pertumbuhan bakteri Staphylococcus aureus (Agustie, 2013).

Identifikasi fitokimia dilakukan dengan metode skrining fitokimia yaitu tahap pendahuluan dalam suatu penelitian fitokimia yang bertujuan untuk memgetahui golongan senyawa yang terkandung dalam tanaman yang sedang diteliti. Metode skrining fitokimia dilakukan dengan melihat 
reaksi pengujian warna dengan menggunakan suatu pereaksi warna (Kristianti dkk., 2008 dalam Dewi dkk., 2013).

Metode yang digunakan untuk melakukan identifikasi alkaloid harus memenuhi beberapa persyaratan antara lain: sederhana, cepat dapat dilakukan dengan peralatan minimal, selektif terhadap golongan senyawa yang dipelajari dan dapat memberikan keterangan tambahan ada atau tidaknya senyawa tertentu dari golongan yang dipelajari (Mustarichie dkk., 2011). Golongan senyawa fitokimia yang akan diidentifikasi pada daun kelor yaitu senyawa alkaloid.

\begin{abstract}
METODE PENELITIAN
Jenis penelitian ini yaitu deskriptif observasional. Untuk mendeskripsikan hasil identifikasi alkaloid daun kelor pada uji laboratorium. Penelitian ini menggunakan sampel ekstrak perasan daun kelor. Ekstrak yang digunakan memakai metode ekstraksi perasan. Esktraksi menggunakan 260 gram daun kelor, setelah di ekstrak mendapatkan hasil ekstrak kental sebanyak 80 gram. Hasil rendemen yang didapatkan dari eksraksi tersebut adalah 30,7\%. Langkah selanjutnya yang dilakukan yaitu melalukan identifikasi daun kelor.
\end{abstract}

\section{HASIL PENELITIAN}

Hasil identifikasi tercantum pada tabel 1 berikut:

Tabel 1. Hasil Identifikasi Alkaloid Daun Kelor

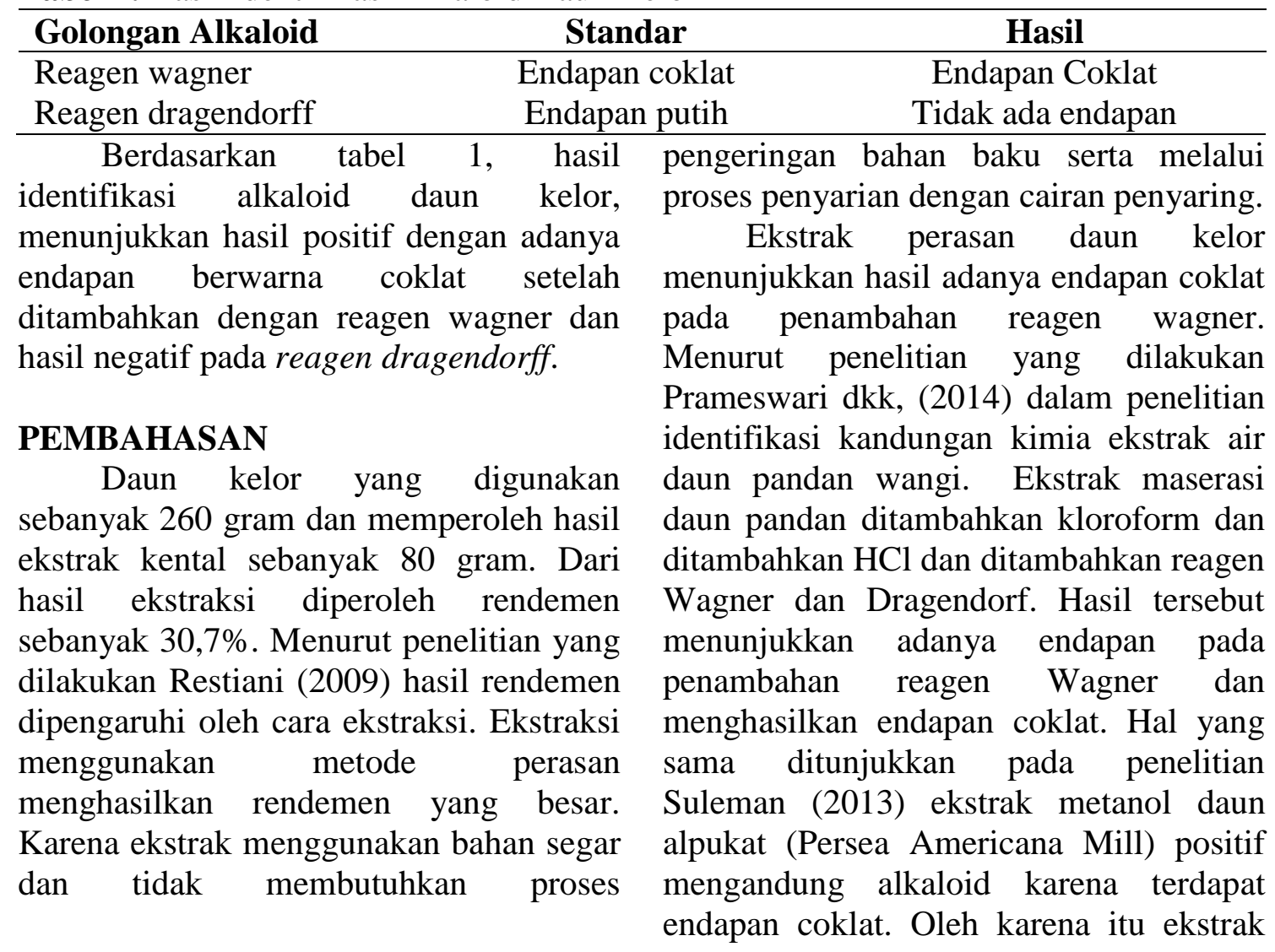


perasan kulit buah naga super merah positif mengandung alkaloid.

\section{KESIMPULAN DAN SARAN}

Kesimpulan hasil penelitian ini, ekstrak perasan daun kelor mengandung alkaloid karena menunjukkan adanya endapan pada penambahan reagen wagner dan menghasilkan endapan coklat.

Saran untuk peneliti lain, perlu dilakukan penelitian lebih lanjut secara kuantitatif untuk mengetahui besar kuantitas kandungan golongan senyawa dari ekstrak perasan daun kelor atau menggunakan cara ekstraksi yang berbeda.

\section{DAFTAR RUJUKAN}

Agoes, G. (2009). Teknologi Bahan Alam (Serial Farmasi Industri-2) Edisi Revisi. Bandung: ITB

Amalia, S., Wahyudaningsih S. \& Untari, E. K. (2016). BPOM RI. 2005. Standarisasi Ekstrak Tumbuhan Obat Indonesia. Jakarta : Badan Pengawas Obat dan Makanan

BPOM RI. (2013). Pedoman Teknologi Formulasi Sediaan Berbasis Ekstrak volume 2. Jakarta : Badan Pengawas Obat dan Makanan Republik Indonesia

Jurnal Farmasi Udayana. Hanani, E. (2014). Analisis Fitokimia. Jakarta: Kedokteran EGC

Katno. (2008). Pengelolaan Pasca Panen Tanaman Obat. DepKes RI: B2P2TOOT.

Mustarichie, R., Musfiroh, I. \& Levita, J. (2011). Metode Penelitian
Tanaman Obat. Bandung: Widya Padjadjaran.

Notoatmodjo, S. (2012). Metodologi Penelitian Kesehatan. Jakarta: Rineka Cipta

Rompas, D. E. B., Runtuwene, M. R. J. \& Koleangan, H. S. J. (2012). Analisis Kandungan Fitokimia dan Uji Aktivitas Antioksidan dari Tanaman Lire (Hemigraphis repanda L. Hall F.). Jurnal MIPA Unsrat Online 5 (1) 36- 39 .

Sugiyono. (2012). Metode Penelitian Kuantitatif, Kualitatif. Bandung: Alfabeta. Sugiyono.

Suleman, N., Tengo, N. A. \& Bialangi, N. (2013). Isolasi dan Karakterisasi Senyawa Alkaloid dari Daun Alpukat (Persea Americana Mill). Jurnal Kimia Universitas Negeri Gorontalo.

Tukiran, Suyatno \& Hidayati, N. (2014).

Skrining Fitokimia pada Beberapa Ekstrak dari Tumbuhan Bugenvil (Bouganvillea glabra), Bunga Sepatu (Hibiscus rosa-sinensis L) dan Daun Ungu (Graptohylum pictum Griff). Prosiding Seminar Nasional Kimia, ISBN: 978-602-0951-00-3.

Wardhani, L. K. \& Sulistyani N. (2012). Uji Aktivitas Antibakteri Ekstrak Etil Asetat Daun Binahong (Anredera Scandens (L.) Moq.) terhadap Shigella Flexneri beserta Profil Kromatografi Lapis Tipis. Jurnal Ilmiah Kefarmasian, Vol. 2, No. 1, 2012 : 1-1 